HORTSCIENCE 25(7):802-803. 1990

\title{
A Fertile Tetraploid Anigozanthos Hybrid Produced by in Vitro Colchicine Treatment
}

\author{
R.J. Griesbach \\ U.S. Department of Agriculture, Agricultural Research Service, Florist \\ and Nursery Crops Laboratory, Beltsville, MD 20705
}

Additional index words. kangaroo paws, polyploidy, allopolyploid

\begin{abstract}
Kangaroo paw is a new cut flower crop native to Australia. There are several interspecific hybrids with improved flower colors, heat tolerance, and growth habit. These hybrids are sterile due to divergent evolution of the parent species. Colchicine was used to double the chromosome number of one important sterile hybrid. This hybrid is everblooming. dwarf. and heat tolerant. The resulting allodiploid was fertile, and progeny are now being evaluated.
\end{abstract}

Anigozanthos, or kangaroo paw, is an herbaceous, Australian perennial with a growth habit similar to a rhizomatous iris. The natural habitat is in a Mediterranean climate with summer drought and winter rain. Anigozanthos species are dormant in the summer and flower during the winter growing season (Roh \& Lawson, 1987; Roh et al., 1986).

Eleven species have been described, in cluding A. bicolor, A. flavidus, A. fuliginosa, A. gabrelae, A. humilis, A. kalbarriensis, A. manglesii, A. onycis, A. pulcherrimus, A. rufus, and $A$. viridis (Roh et al., 1986). Primary hybrids between all the Anigozanthos species have been produced, as well as a few secondary and tertiary hybrids. A single clone ('Bush Ranger') from Mervyn Turner's cross of A. humilis x A. flavidus is being distributed by Biotech Plants, Australia. Unlike the other Anigozanthos species and hybrids, this clone does not become dormant during the summer, and it flowers continuously all year. Since 'Bush Ranger' is a primary hybrid, it is genetically sterile. This project was undertaken to produce a fertile amphidiploid of 'Bush Ranger' through colchicine treatment.

Axillary vegetative buds of 'Bush Ranger' were aseptically removed from actively growing plants and placed on an in vitro proliferation medium (Ellyard, 1978) that contained Murashige and Skoog (1962) salts and vitamins, $30 \mathrm{~g}$ sucrose/liter, $8 \mathrm{~g}$ phytoagar

Received for publication 3 Aug. 1989. I thank Ron Beck for his technical assistance and the Fred C. Gloeckner Foundation for support. The cost of publishing this paper was defrayed in part by the payment of page charges. Under postal regulations, this paper therefore must be hereby marked advertisement solely to indicate this fact.
(Gibco)/liter and $0.5 \mathrm{mg}$ NAA/liter. After 1 month, the newly formed shoots were placed on proliferation medium supplemented with $0.1 \%$ colchicine, as previously described by Griesbach (1981) for orchids. The single shoots were incubated on this medium for 1 week and then placed back on standard proliferation medium. After 6 months of continued growth and proliferation, individual shoots were collected and rooted on a medium (Ellyard, 1978) containing Murashige and Skoog salts and vitamins, $0.2 \mathrm{mg}$ NAA/ liter, $20 \mathrm{~g}$ sucrose/liter, and $8 \mathrm{~g}$ phytoagar/ liter. All cultures were maintained at $25 \mathrm{C}$ with $16 \mathrm{hr}$ daylight, $260 \mu \mathrm{mol} \cdot \mathrm{s}^{-1} \cdot \mathrm{m}^{-2} \mathrm{cool}-$ white fluorescent illumination. Rooted plants were established in a greenhouse under natural conditions. Chromosomes were counted using the standard acetocarmine technique (McClintock, 1929).

Five shoots were treated with colchicine. About five lateral offshoots developed from each shoot tip after 6 months of culture on proliferation medium. Two of the shoots did not produce tetraploid offshoots. Of the other three shoots, two produced one tetraploid offshoot each and the other produced two.

Table 1. Floral characteristics of the diploid and tetraploid 'Bush Ranger'. Values are reported as the mean of five flowers plus or minus the standard deviation times the 1 value at $95 \%$ probability.

\begin{tabular}{lcc}
\hline $\begin{array}{c}\text { Flower } \\
\text { dimension } \\
(\mathrm{cm})\end{array}$ & $\begin{array}{c}\text { Diploid } \\
\text { Bush Ranger }\end{array}$ & $\begin{array}{c}\text { Tetraploid } \\
\text { Bush Ranger }\end{array}$ \\
\hline Flower width & $3.33 \pm 0.12$ & $3.77 \pm 0.12$ \\
Ovary diameter & $0.48 \pm 0.06$ & $0.68 \pm 0.06$ \\
Petal width & $0.25 \pm 0.10$ & $0.33 \pm 0.06$ \\
Petal length & $2.12 \pm 0.06$ & $2.47 \pm 0.12$ \\
\hline
\end{tabular}




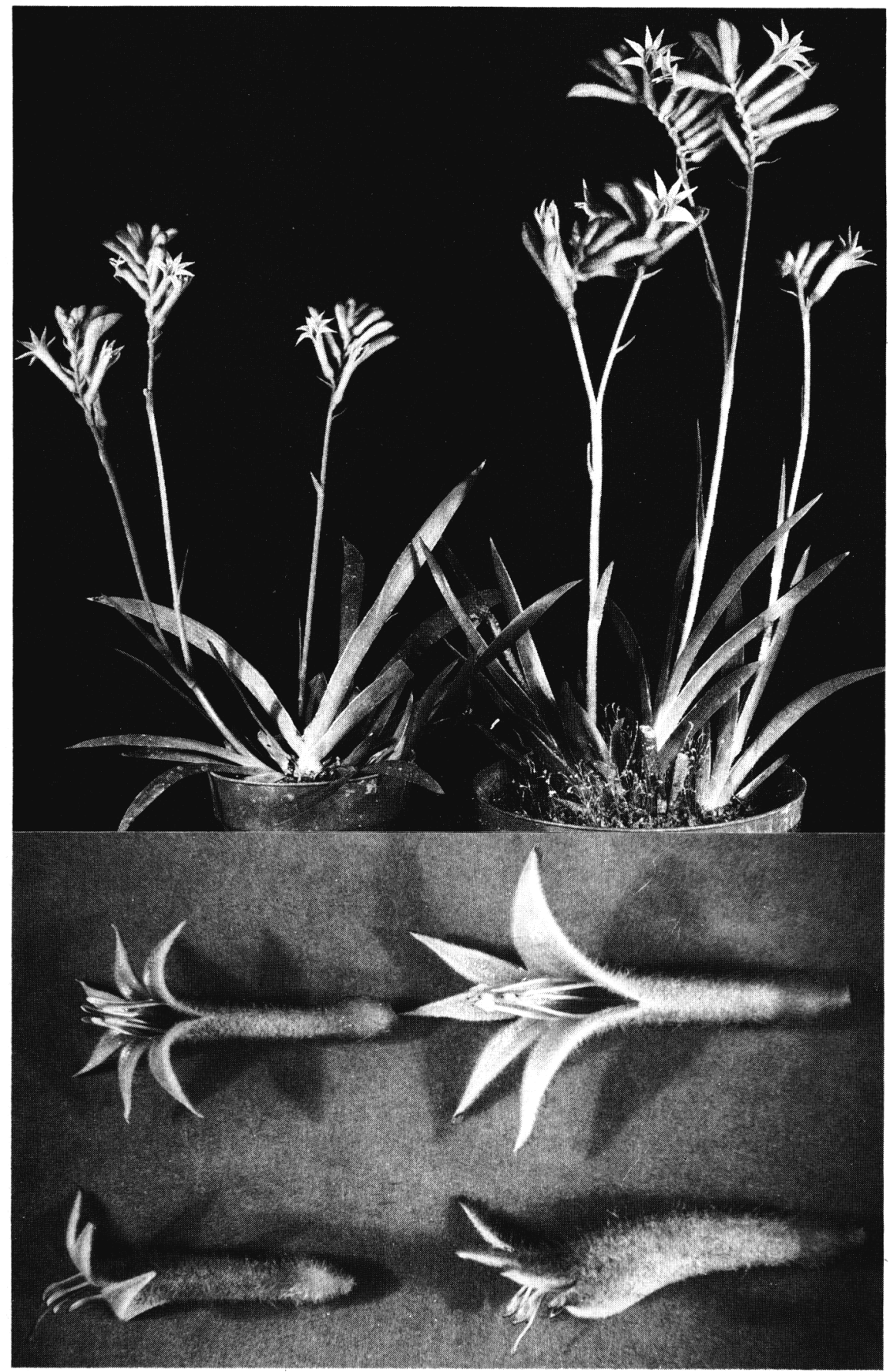

Fig. 1. Comparison of diploid and tetraploid plants (top) and flowers (bottom) of 'Bush Ranger' Anigozunthos. Diploid form is on the left.

The tetraploid offshoots were further proliferated in culture to assure their nonchimeral nature. No diploid offshoots developed from any of the tetraploid shoots. The tetraploid plants were rooted and evaluated in- the

The tetraploid form of 'Bush Ranger' had

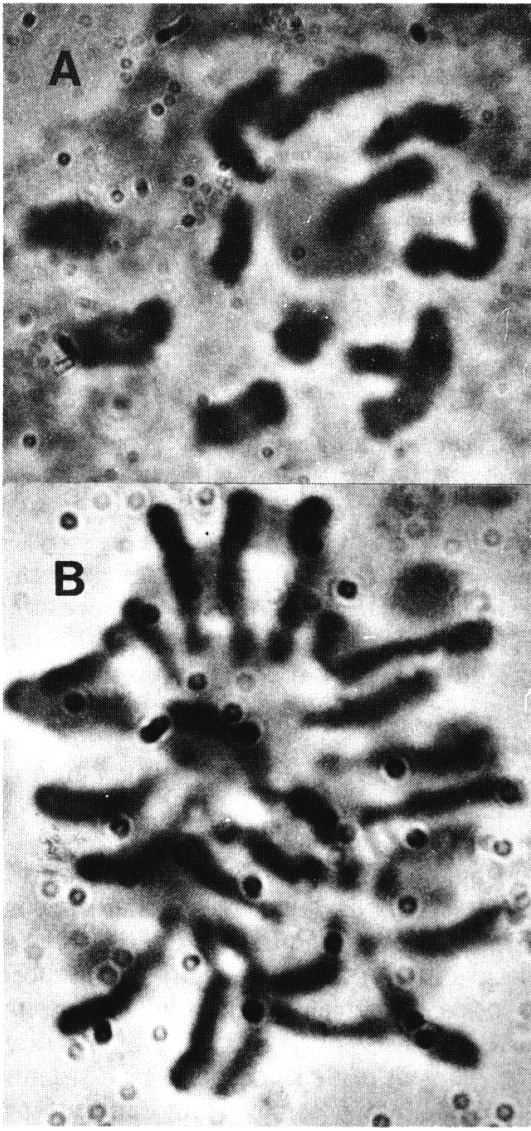

Fig. 2. Comparison of the chromosome number of 'Bush Ranger' Anigozanthos. (A) diploid 2n $=2 \mathrm{x}=12 ;(\mathbf{B})$ tetraploid $2 \mathrm{n}=4 \mathrm{x}=24$.

proved horticultural merit, the tetraploid 'Bush Ranger' is fertile. It is now being evaluated for pot plant production and will be released through the USDA-SAF New Crops Program.

\section{Literature Cited}

Ellyard, R.K. 1978. In vitro propagation of Anigozanthos manglesii, flavidus, and Macropidia fuliginosa. HortScience 13:662-663.

Griesbach, R.J. 1981. Colchicine-induced polyploidy in Phalaenopsis orchids. Plant Cell Tissue Organ Cult. 1:103-107.

McClintock, B.A. 1929. A method for making acetocarmine smears. Stain Technol. 4:53-56.

Murashige, T. and F. Skooa. 1962. A revised medium for rapid growth and bioassays with tobacco tissue cultures. Physiol. Plant. 15:479497.

Roh, M. and R.H. Lawson. 1987. Kangaroo paws-A classy new floral experience. Greenhouse Manager 5:86-108. larger, fuller, flatter florets than the diploid (Table 1), taller inflorescences and a stouter plant habit (Figs. 1 and 2). Besides its im-
Roh, M., R.H. Lawson, and R.G. Anderson. 1986. The kangaroo paw-A new crop for U.S. production. Grower Talks 50:80-87. 